\title{
An investigation on renewable energy education at the university level in Turkey
}

\author{
Abdurrahman Karabulut ${ }^{a}$, Engin Gedik ${ }^{b}$, Ali Keçebaş ${ }^{a, *}$, Mehmet Ali Alkan $^{c}$ \\ ${ }^{\text {a }}$ Faculty of Technical Education, Afyon Kocatepe University, Afyon, Turkey \\ ${ }^{\mathrm{b}}$ Faculty of Technical Education, Karabuk University, Karabuk, Turkey \\ ${ }^{\mathrm{c}}$ Ula Ali Kocman Vocational High School, Mugla University, Mugla, Turkey
}

\section{A R T I C L E I N F O}

\section{Article history:}

Received 9 August 2010

Accepted 5 October 2010

Available online 23 October 2010

\section{Keywords:}

Renewable energy sources

Geothermal

Solar

Wind

Education

\begin{abstract}
A B S T R A C T
In the present study, to discover how teaching of renewable energy sources in Turkey is carried out at the university level, a questionnaire was developed and applied at different universities in Turkey. The analyses conducted on the data obtained from the questionnaire revealed that education about geothermal, solar and wind energy is given at master's level, other renewable energy sources are taught at the undergraduate level within the curriculum of some engineering courses. The teaching performed about renewable energy sources is in Turkish and at encyclopedic level. As preparing and obtaining the required materials are costly, some problems are encountered in the teaching of renewable sources. In Turkish universities, no degree about renewable energy sources is granted. Hence, the country must make use of the people having engineering degree to capitalize on its renewable energy sources. As there is no program specializing on providing training about the renewable energy sources, it seems to be difficult to find experts about this issue. The current state of renewable energy sources education seems to be inadequate and it should be expanded and strengthened.
\end{abstract}

(ㄷ) 2010 Elsevier Ltd. All rights reserved.

\section{Introduction}

Today, one of the most important indicators showing the development level of countries is the consumption of energy that is the major input in the fields of technology and industry. Due to increasing energy needs of the countries as a result of developing technology, the exploitation of the fossil fuels has increased and this naturally led to more environmental problems that can be overcome with the widespread use of the renewable energy sources; hence, the work about renewable energy sources has gained a momentum. Depletion of the limited sources of the fossil fuels and their adverse effects on the environment result in shifting focus towards renewable energy sources. The main problems still to be solved in the whole world are i) increasing demand for energy, ii) fast depletion of the non-renewable energy sources and iii) local and universal environmental pollution [1].

As in the world, Turkey is confronted with many problems such as high energy demand, decrease in the amount of sources apart from renewable energy sources and environmental pollution [2]. The means of overcoming these problems seems to be the effective use of renewable energy sources [3]. Moreover, scientists in Turkey are making a projection of a bright future in terms of the use of renewable energy with the Development and Research works they

\footnotetext{
* Corresponding author. Tel.: +90 272 2281311/370 (off); fax: +90 2722281319.

E-mail address: alikecebas@aku.edu.tr (A. Keçebaş).
}

have been conducting. However, the education provided about the renewable energy sources seems to be overlooked.

Renewable energy sources education is a relatively new field in general education. In Turkey, renewable energy education is mostly provided at tertiary level. Before looking at the state of renewable energy education in Turkey, first we look at the situation in the world. There are many studies conducted in this field in the world [4-15].

When the literature is reviewed, it is seen that there are a few studies conducted in this field in Turkey [16-18]. The majority of the renewable energy sources-related studies focus on the energy potential of Turkey [19-21]. In these studies, it is seen that there is a deep theoretical accumulation, but there seems to have some problems in practice and promotion of the ideas in the public. The present study aims to highlight the situation of the renewable energy education in Turkey and what should be done to disseminate the findings in the field.

\section{Methodology}

In the present study, the state of the education of renewable energy sources in Turkish universities and what should be done to enhance it are determined. In the light of the literature review, a questionnaire was developed (Appendix A) and applied in the faculties, departments and research centers dealing with the renewable energy sources of different universities. 
Table 1

Number of the faculty members from the universities participating in the study.

\begin{tabular}{lcc}
\hline Universities in Turkey & Frequencies & Percentages (\%) \\
\hline Atatürk University & 19 & 14.2 \\
Dokuz Eylül University & 6 & 4.5 \\
Dumlupinar University & 9 & 6.7 \\
Ege University & 6 & 4.5 \\
Firat University & 13 & 9.7 \\
Gebze Institute of Technology & 11 & 8.2 \\
Inönü University & 17 & 12.7 \\
Karabük University & 7 & 5.2 \\
Mersin University & 14 & 10.4 \\
Muğla University & 4 & 2.8 \\
Pamukkale University & 7 & 5.2 \\
Sakarya University & 6 & 4.5 \\
Süleyman Demirel University & 10 & 7.5 \\
Yıldı Technical University & 5 & 3.7 \\
Total & 134 & 100.0 \\
\hline
\end{tabular}

\section{Results and discussion}

The questionnaire used in the study focuses on seven main topics i) Characteristics of universities and faculty members; ii) Fields of renewable energy education; iii) Level of renewable energy education; iv) Degrees given; v) Depth of education; vi) Literature of renewable energy education, vii) materials and equipment used in the education.

The present study was carried out among 14 different Turkish universities. In these universities, there are 36 faculties, 40 departments and 15 research centers. The questionnaire used in the study focuses on six main topics i) Characteristics of universities and faculty members; ii) Fields of renewable energy education; iii) Level of renewable energy education; iv) Degrees given; v) Depth of education; vi) Literature of renewable energy education. Following results were obtained from the questionnaire.

\subsection{Faculties and Education staff}

134 faculty members from 14 different universities participated in the study. Almost all of these universities deliver renewable energy education. The faculty members of these universities
Table 2

Characteristics of faculty members at the universities.

\begin{tabular}{lcc}
\hline & Frequencies & Percentages (\%) \\
\hline No answer & 4 & 3.0 \\
Lecturers working at different faculties & 30 & 22.4 \\
Lecturers in specific faculties & 77 & 57.5 \\
Others & 23 & 17.2 \\
Total & 134 & 100.0 \\
\hline
\end{tabular}

conduct pioneering studies in the field of renewable energy (see Table 1); hence, the questionnaire was administered in these universities.

Academic titles of the participants are presented in Fig. 1. Majority of the participants are Assistant Professors. The ratio of the research assistants is also remarkable. This may indicate that the number of the academic personnel who will study renewable energy sources in the future will be high. General characteristics of the participating faculty members are presented in Table 2. According to this table, $57.5 \%$ of the faculty members work in their own faculties as lecturers and $22.4 \%$ work in different faculties as lecturers.

The number of the students having education about renewable energy sources is presented in Table 3. There are 3500 undergraduate students having education about renewable energy sources at these universities. However, the number of the students having education at master's level is lower. This is an interesting finding as in general in Turkey renewable energy education is initiated at master's level.

\subsection{Education field}

The questionnaire (Appendix A) defines the fields as solar, wind, geothermal, hydraulic etc. energy sources. Table 4 presents the fields in which the universities give education about renewable energy sources. According to this table, the field where the most extensive education is given is geothermal renewable sources (31.3\%) and this is followed by solar energy (16.4\%), wind energy (15.7\%) and hydraulic energy (9\%). Though the currently most commonly used renewable energy sources in Turkey are hydraulic

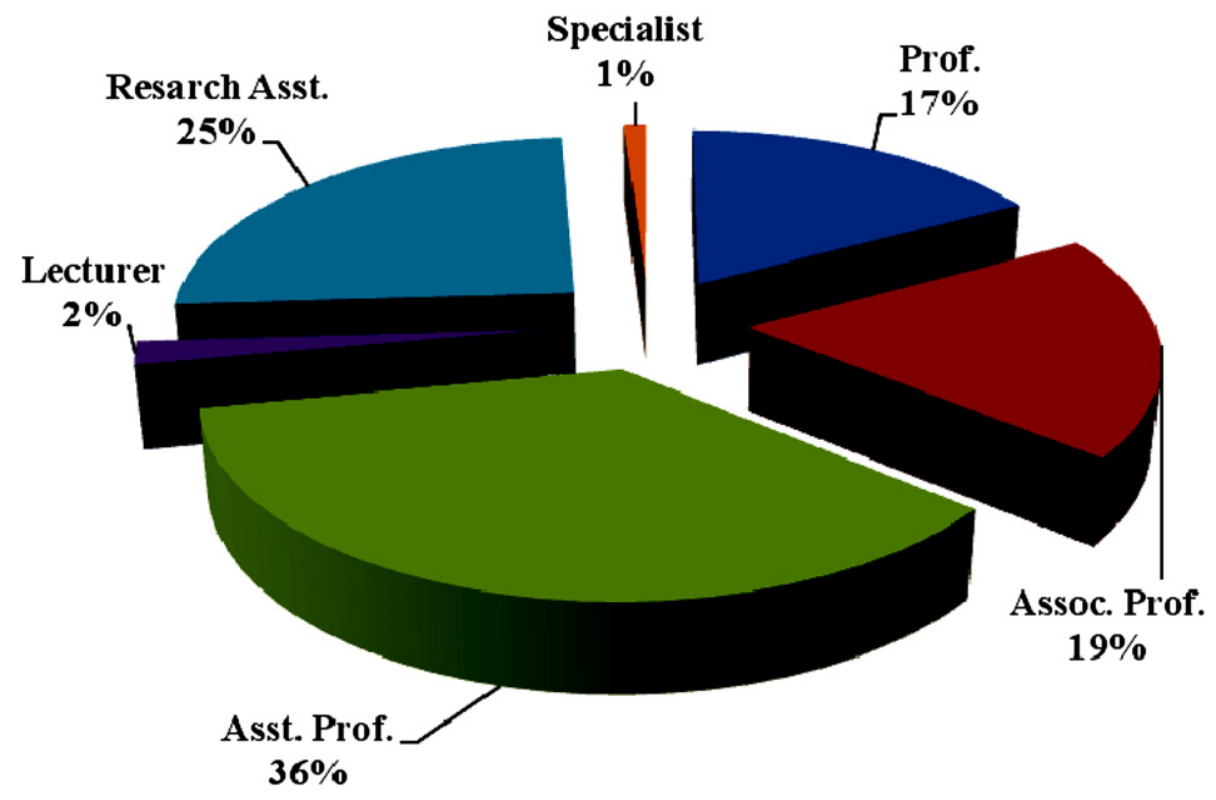

Fig. 1. Titles of the Education staffs. 
Table 3

The number of the students having education about renewable energy sources.

\begin{tabular}{cllllll}
\hline & Undergraduate & Master & Doctorate & $\begin{array}{l}\text { Post } \\
\text { doctorate }\end{array}$ & $\begin{array}{l}\text { Visiting } \\
\text { students }\end{array}$ & Course \\
\hline $\begin{array}{c}\text { Number } \\
\text { of the } \\
\text { students }\end{array}$ & 3500 & 179 & 76 & 3 & - & - \\
\hline
\end{tabular}

Table 4

Renewable energy sources about which education is given at universities.

\begin{tabular}{lcc}
\hline & Frequencies & Percentages (\%) \\
\hline Solar energy & 22 & 16.4 \\
Wind energy & 21 & 15.7 \\
Geothermal energy & 42 & 31.3 \\
Hydraulic energy & 19 & 14.2 \\
Hydrogen energy & 12 & 9.0 \\
Bio-mass energy & 16 & 11.9 \\
Tidal energy & 1 & 0.7 \\
Others & 1 & 0.7 \\
Total & $\mathbf{1 3 4}$ & $\mathbf{1 0 0 . 0}$ \\
\hline
\end{tabular}

Table 5

Institutions thought to be necessary to improve the field of renewable energy.

\begin{tabular}{lll}
\hline & Frequencies & Percentages (\%) \\
\hline Universities & 116 & 86.8 \\
State government & 111 & 82.8 \\
Local governments & 64 & 47.8 \\
Primary and secondary schools & 20 & 14.9 \\
Families & 19 & 14.2 \\
\hline
\end{tabular}

and classical bio-mass energy sources, the education given at the universities attach more importance to geothermal, solar and wind energy sources.

Table 5 presents the institutions thought to be necessary to improve the field of renewable energy. According to the table, universities are regarded the most necessary institutions. In addition, state and local governments are considered to be important to provide support for the universities. Primary and secondary schools and families are viewed to be important to start renewable energy sources education.

\subsection{Education level}

Table 6 presents the faculties giving renewable energy sources education at the universities. Among these faculties, engineering faculties come first (72.4\%) at giving education about renewable energy sources.

As can be seen in Table 7, the most extensive renewable energy education is given at master's programs (45.5\%) and this is followed by PhD level $35.1 \%$. Usually the researchers start to specialize on renewable energy sources at the master's level. At undergraduate level, it is observed that higher priority is given to the classical engineering subjects than renewable energy sources-related subjects. Special

Table 6

Faculties giving education about renewable energy sources.

\begin{tabular}{lcc}
\hline & Frequencies & Percentages (\%) \\
\hline Technical education faculty & 29 & 21.6 \\
Engineering faculty & 97 & 72.4 \\
Faculty of science and letters & 5 & 3.7 \\
Others & 3 & 2.2 \\
Total & $\mathbf{1 3 4}$ & $\mathbf{1 0 0 . 0}$ \\
\hline
\end{tabular}

Table 7

Level of education given at faculties.

\begin{tabular}{lcc}
\hline & Frequencies & Percentages (\%) \\
\hline Undergraduate & 23 & 17.2 \\
Master's & 61 & 45.5 \\
PhD & 47 & 35.1 \\
Special courses etc. & 3 & 2.2 \\
Total & $\mathbf{1 3 4}$ & $\mathbf{1 0 0 . 0}$ \\
\hline
\end{tabular}

Table 8

Courses given about renewable energy sources.

\begin{tabular}{lcc}
\hline & Frequencies & Percentages $(\%)$ \\
\hline Elective courses & 50 & 37.3 \\
Required courses & 15 & 11.2 \\
Both elective and required & 16 & 11.9 \\
As a part of a course & 53 & 39.6 \\
Total & $\mathbf{1 3 4}$ & $\mathbf{1 0 0 . 0}$ \\
\hline
\end{tabular}

courses and similar activities about renewable energy sources are fewer at universities (2.2\%).

\subsection{Diploma of Education}

It is seen that no diploma about renewable energy sources is granted at the undergraduate level at Turkish universities. Usually, such diplomas are granted at master's and PhD levels.

\subsection{Depth of education}

Table 8 presents the state of the courses given about the energy sources in relation to their being required or elective. Here, it is seen that $37.3 \%$ of the courses presented are elective. In addition, 39.6\% of the courses reserve some place for renewable energy sources in their curriculums. Low percentage of required courses indicates that not many educational activities are performed about renewable energy sources.

Table 9 presents what kinds of benefits are brought about by the existence of the renewable energy-related topics at undergraduate level. According to this table, it is seen that for students to be equipped with general information on the renewable energy resources, there should be some courses about the renewable energy sources at undergraduate level. Those who want to specialize on renewable energy should have their master's and PhD

Table 9

Topics on renewable energy sources in undergraduate curriculums.

\begin{tabular}{lcc}
\hline & Frequencies & Percentages(\%) \\
\hline $\begin{array}{l}\text { Students' having general } \\
\text { information on } \\
\text { renewable energy sources }\end{array}$ & 49 & 36.6 \\
$\begin{array}{l}\text { Students' interest on } \\
\text { renewable energy-related } \\
\text { topics }\end{array}$ & 22 & 16.4 \\
$\begin{array}{l}\text { Renewable energy information } \\
\text { may help to find better job } \\
\text { opportunities }\end{array}$ & 9 & 6.7 \\
$\begin{array}{l}\text { Renewable energy information } \\
\text { may create new job } \\
\text { opportunities }\end{array}$ & 22 & 16.4 \\
$\begin{array}{l}\text { Renewable energy information } \\
\text { helps to be involved in energy } \\
\text { design and research }\end{array}$ & 32 & 23.9 \\
Total & $\mathbf{1 3 4}$ & $\mathbf{1 0 0 . 0}$ \\
\hline
\end{tabular}


Table 10

Renewable energy-related topics that should be taught to the undergraduate students.

\begin{tabular}{lcc}
\hline & Frequencies & Percentages(\%) \\
\hline Energy crisis and sustainability & 8 & 6.0 \\
Solar energy technologies & 23 & 17.2 \\
Geothermal energy technologies & 15 & 11.2 \\
Other energy technologies & 17 & 12.7 \\
The use of fossil fuels & 20 & 14.9 \\
Bio-mass technologies & 5 & 3.7 \\
Wind energy technologies & 20 & 14.9 \\
Hydrogen energy technologies & 10 & 7.5 \\
Energy economies & 15 & 11.2 \\
Energy management & 1 & 0.7 \\
Total & $\mathbf{1 3 4}$ & $\mathbf{1 0 0 . 0}$ \\
\hline
\end{tabular}

Table 11

Number of the courses concerning the teaching of renewable energy sources.

\begin{tabular}{llll}
\hline & $\begin{array}{l}\text { Technical } \\
\text { education faculty }\end{array}$ & $\begin{array}{l}\text { Engineering } \\
\text { faculty }\end{array}$ & $\begin{array}{l}\text { Faculty of science } \\
\text { and letters }\end{array}$ \\
\hline Undergraduate & 9 & 19 & 9 \\
Master's & 5 & 11 & 6 \\
PhD & 8 & 10 & 5 \\
Post doctorate & - & - & - \\
\hline
\end{tabular}

degrees. The job opportunities in the field of renewable energy are directly related with the interest level of the students.

The sequencing of the topics that should be taught to the students at the undergraduate level at universities according to their importance is presented in Table 10. According to this table, it is seen that the first topic to be taught should be solar energy technologies and this is followed by the use of fossil fuels, energy economy, and geothermal energy technologies.

The number of the courses concerning the teaching of renewable energy sources is presented in Table 11. According to this table, the greatest number of courses is given at engineering faculties. The technical education faculties and faculties of science and letters follow them.

Table 12 presents the structure of the courses given about renewable energy sources. $59 \%$ of the courses given at the undergraduate level are theory-based, $28.4 \%$ of the courses given at the master's level are both theory and practice based. Therefore, it can be claimed that the courses given at the master's level are conducted with more application.

\subsection{Material and equipments}

The percentages values showing the ratios of the materials used in the renewable energy courses given at universities are presented in Table 13. According to this table while teaching solar energy, wind energy and hydrogen energy, mostly national and international text books are used, on the other hand, while teaching wind

Table 12

The structure of the courses given about renewable energy sources at the universities (\%).

\begin{tabular}{llll}
\hline & Theory-based & $\begin{array}{l}\text { Application } \\
\text { based }\end{array}$ & $\begin{array}{l}\text { Both theory } \\
\text { and application } \\
\text { based }\end{array}$ \\
\hline Undergraduate & 59.0 & 6.0 & 10.4 \\
Master & 23.9 & 5.2 & 28.4 \\
PhD & 27.6 & 10.4 & 9.7 \\
Post doctorate & - & - & 1.5 \\
\hline
\end{tabular}

Table 13

Materials used to teach renewable energy in courses at universities.

\begin{tabular}{lrcr}
\hline & $\mathrm{a}$ & $\mathrm{b}$ & $\mathrm{c}$ \\
\hline Solar energy & 44.8 & 25.4 & 15.7 \\
Wind energy & 29.1 & 32.1 & 6.0 \\
Geothermal energy & 17.2 & 25.4 & 9.7 \\
Hydraulic energy & 4.5 & 1.5 & 23.9 \\
Hydrogen energy & 28.4 & 19.4 & 10.4 \\
Current energy & 2.2 & - & 6.0 \\
Bio-mass energy & 9.0 & 9.7 & 2.2 \\
Tidal energy & 1.5 & 6.0 & 0.7 \\
\hline
\end{tabular}

$\mathrm{a}$ is National and international text books (\%).

$\mathrm{b}$ is Articles and similar resources (\%).

c is Experiment, equipment, models (\%).

energy, articles etc. are used and while teaching hydraulic energy, experimental studies are used.

\section{Conclusion}

The places where scientific and technological process most effectively continues are universities. The number of the assistant professors and research assistants engaging in the issue of renewable energy is steadily increasing. In this respect, the future seems to be promising. However, though the number of the students at undergraduate level is high, the courses dealing with the renewable energy sources at this level are few; therefore, the present number of people working in this field is not much. Hence, it claims that renewable energy education given at the undergraduate level only aims to arouse the interest of the students. People usually start specializing on renewable energy at the master's level but number of the students having a master's degree on renewable energy sources is lower. Accordingly, the number of academicians working in this field at universities is lower.

In Turkey, renewable energy education is mostly given by engineering faculties. And the depth of the energy education given here is restricted to arousing students' interests within the context of classical science and engineering education. Teaching is at the encyclopedic level. While information about non-renewable energy and hydraulic energy is given at the undergraduate level, information is given about geothermal energy, solar energy, and wind energy at master's level.

Resources and materials used in renewable energy education are prepared and presented in Turkish. Materials used are expensive and this may lead to some problems. Materials used at master's and $\mathrm{PhD}$ levels are revised and renewed almost each year. And the use of such materials at undergraduate level is not very common.

At present, there is no undergraduate program granting diploma on renewable energy sources in Turkey. Usually such diplomas and certificates are granted at master's and doctorate levels. Hence, such diplomas should be granted at the undergraduate level. Usually, graduates of the engineering programs are employed in the field of renewable energy. Lack of undergraduate programs granting diploma about renewable energy sources result in the shortage of experts in the field.

Education plays a role at three levels in the fields of science and technology. These are: low level for personnel and researchers, middle level for technicians and qualified workers. The aim of this education is to give priority to the teaching of science and technology and to find solutions to daily problems. There are many problems faced in science teaching in the country. There are shortages of equipment and laboratory materials required by such education.

There is a need for various education programs to meet the need for qualified personnel in the country. Such education programs 
should take the advancements in the fields of science and technology into consideration. To plan and carry out successful projects, there is a need for the training of qualified technical personnel.

Constant increase seen in the price and consumption of energy results in attaching greater importance to the effective use of energy and research and development efforts for the renewable energy resources. Naturally, this leads to greater awareness of the importance of energy and developing energy education programs.

Today, energy education should focus on the use of renewable energy and energy equipment but due to expenses involved in the provision of materials required for energy education, some problems are encountered. Moreover, even if such materials are provided, the qualified personnel to use these materials may be another problem.

\section{Appendix A. Questionnaire}

Faculties and Education staff

University/Institution that you are affiliated to:

Faculty/Institute/Research Center/Research and Development department:

Department/Laboratory:

What is the number of the academicians teaching courses in RES departments?: (Prof.; Assoc. Prof.; Asst. Prof.; Lecturer; Research Asst.; Specialist)

What are the features of the academicians teaching RES courses?: (-General lecturer; - Lecturers working at different faculties; -Lecturer at some specific departments (solar, wind, geothermal etc.); -Others)

What is the number of the students having RES education at your university?: (Two-year degree programs; Undergraduate; Master; Doctorate; Post doctorate; Guest student; Course)

\section{Education field}

Which renewable energy sources are investigated at your university? (You may select more than one.): (Solar; Wind; Geothermal; Hydraulic; Hydrogen; Current; Biomass; Tidal and Flow; Others)

How much do you think the following organizations are necessary for the use of renewable energy sources?: (State; Universities and Research Institutes; Primary and secondary schools; Local governments; Families)

\section{Education level}

Which faculties give RES education at the undergraduate level?: (Technical Education Faculty; Engineering Faculty; Faculty of Science and Letters)

At which kevels education about RES is given at your university? (You may select more than one.): (Two-year degree programs; Undergraduate; Master; Doctorate; Courses)

\section{Depth of education}

Does your university organize any education program, course, seminar for RES?:

Please answer the following questions about the courses teaching RES (Yes or No): (-Elective courses; -Required courses; -Both elective and required courses; -Part of a course)

What do you think about the presence of renewable energy as a topic in the undergraduate curriculum?: (-Students should have general knowledge about renewable energy-related issues and technologies; -In this way, students may feel interested in renewable energy; -Renewable energy information may help them to be more effective in their jobs; -Renewable energy information may help them to find new job opportunities; -Renewable energy information may provide them with new design and research opportunities)

Which one can be taught to undergraduate students?: (-Energycrisis and sustainability; -Biomass technologies; -Solar energy tech nologies; -Wind energy technologies; -Geothermal energy technologies; -Hydrogen energy technologies; -Other energy technologies; -En ergy economy; -Environmental effects of using fossil fuels; -Energy conversation/management)

What is the number of the courses given about RES?:

Fill in the table given below in line with your opinions about the structure of RES courses given at your university:

\section{Material and equipments}

Fill in the following table concerning the materials used in RES courses at your university: (-National and international text books; -Articles and similar resources; -Experiment, equipment, models).

\section{References}

[1] Bojic M. Education and training in renewable energy sources in Serbia and Montenegro. Renewable Energy 2004;29:1631-42.

[2] Demirbas A. Energy and environmental issues relating to greenhouse gas emissions in Turkey. Energy Conversion and Management 2003;44:203-13.

[3] Cetinkaya S. Renewable energy opportunities in Turkey. PowerGen renewable energy and fuels. Las Vegas, NK, USA, http://www.authorstream.-com/ Presentation/Malden-29633-17-PowerGen-Renewable-EnergyLasVegasMarch-1-3-2005-Energy-Opportunities-Turkey-asEntertainmentpptpowerpoint/; March 2005 [last visit on December 2009].

[4] Buckley RW, Kuetz EA. European photovoltaic education initiative. Renewable Energy 1994;5:345-7.

[5] Broman L. On the didactics of renewable energy education-drawing on twenty years experience. Renewable Energy 1994;5:1398-405.

[6] Garg H, Kandpal T. Energy engineering education at postgraduate level: issues involved, course structure and its proposed adaptation. Renewable Energy 1994:5:1406-12.

[7] Garg H, Kandpal T. Renewable energy education: challenges and problems in developing countries. Renewable Energy 1996;9:1188-93.

[8] Ruzinsky M, Smola A, Takacs J, Saly V, Ruzinska D, Darula I, et al. Renewable energy $R \& D$, education and training at the Slovak Technical University. Renewable Energy 1996;9:1199-202.

[9] Berkovski B, Gottschalk C. Strengthening human resources for new and renewable energy technologies of the 21st century: UNESCO engineering education and training programme. Renewable Energy 1997;10:441-50.

[10] O'Mara KL, Jennings PJ. Innovative renewable energy education using the world wide web. Renewable Energy 2001;22:135-41.

[11] Bhattacharya SC. Renewable energy education at the university level. Renewable Energy 2001;22:91-7.

[12] Jain PK, Lungu EM, Mogotsi B. Renewable energy education in Botswana: needs, status and proposed training programs. Renewable Energy 2002;25:115-29.

[13] Axaopoulos P, Pitsilis G. Energy software programs for educational use. Renewable Energy 2007:32:1045-58.

[14] Zografakis N, Menegaki AN, Tsagarakis KP. Effective education for energy efficiency. Energy Policy 2008;36:3226-32.

[15] Jennings P. New directions in renewable energy education. Renewable Energy 2009;34:435-9.

[16] Kecebas A, Alkan MA. Educational and consciousness-raising movements for renewable energy in Turkey. Energy Education Science and Technology Part B-Social and Educational Studies 2009;1:157-70.

[17] Kecebas A, Yumurtaci M. Renewable energy and its university level education in Turkey. Energy Education Science and Technology Part B-Social and Educational Studies 2011;3:143-52.

[18] Demirbas A. Energy concept and energy education. Energy Education Science and Technology Part B-Social and Educational Studies 2009;1:85-101.

[19] Ozgur MA. Review of Turkey's renewable energy potential. Renewable Energy 2008;33:2345-56.

[20] Demirbas A. Turkey's energy overview beginning in the twenty-first century. Energy Conversion and Management 2002;43:1877-87.

[21] Sozen A, Arcaklioglu E, Ozalp M, Kanit EG. Use of artificial neural-networks for mapping the solar potential in Turkey. Applied Energy 2004;77:273-86. 